\title{
DZIKIR: PSIKOTERAPI DALAM PERSPEKTIF ISLAM
}

\author{
Rudy Haryanto \\ Dosen Jurusan Syari'ah dan Ekonomi STAIN Pamekasan, \\ Jln. Pahlawan KM. 04 Pamekasan
}

\begin{abstract}
Abstrak
Ada korelasi antara Ilmu Psikologi dan ajaran Islam mengenai dimensi kejiwaan manusia, sehingga masalah gangguan kejiwaan tidak bisa dilepaskan dari keduanya. Kehidupan modern membuat manusia melupakan aspek spiritual yang ada di dalam dirinya. Dorongan spiritual yang tidak terpenuhi pada diri manusia menyebabkan perasaan hampa dan tanpa makna yang berujung kepada terjadinya gangguan kejiwaan. Teknik psikoterapi dikembangkan dalam mengatasi gangguan kejiwaan berdasarkan teori psikologi maupun ke-Islam-an. Dalam ajaran Islam, dzikir yang merupakan tradisi pesantren dan secara rutin dilakukan oleh civitas pesantren merupakan alternatif terapi yang sangat efektif dalam mengatasi gangguan kejiwaan.
\end{abstract}

\section{Abstract:}

The importance of maintaining public order and harmony as a nation and a state particularly relating to freedom of religion or belief which is one part that must be taken seriously by the government and every element in order to avoid conflicts of violence in the name of religion. Based on statement above, that the educational approach, consensus approach and religious proselytizzing approach are preventive efforts "prevention" in tackling crime/violence in the name of religion (cult). Because the approach is essentially for the public awareness in order to believe religious teachings and carry out the religious teaching correctly, as well as the prevention of violence. Preventive efforts are action to anticipate the occurrence of streams insulting and oppression or other religions. But with this preventive policy does not mean that need not to be processed by the 
criminal law but rather as an action towards the elimination of potential factors causing streams and violence in the name of religion.

\section{Kata Kunci:}

Dzikir, Kejiwaan, Psikologi, Psikoterapi, Logoterapy

\section{Pendahuluan}

Ajaran tasawuf dan tarekat tidak bisa dipisahkan dengan pondok pesantren. Di sini seorang kyai selalu memimpin para santri dan jemaahnya mengamalkan amalan-amalan tarekatnya, terutama amalan dzikir sebagai amalan utamanya. Dalam lingkungan pesantren amalan dzikir telah menjadi suatu ciri khas, kebiasaan dan tradisi rutin dalam rangka meningkatkan kualitas kedekatan dan ketaqwaan diri serta mencari keridhaan Allah swt. swt. dan membentengi diri dari pengaruh kehidupan modern yang dipandang dapat merusak tata kehidupan umat Islam.

Masyarakat Islam yang masih mau menghidupkan tradisi dzikir menurut Clifford Geertz ${ }^{1}$ termasuk kelompok Islam pengikut paham Imam Syafi'i yang berhaluan ahlussunnah waljamaah dalam prinsip keagamaannya. Kelompok Islam inilah yang disebut Deliar Noer ${ }^{2}$ sebagai kelompok Islam tradisional yang secara organisasi adalah kelompok Islam Nahdlatul Ulama' yang berbasis di pondok pesantren. ${ }^{3}$

Dalam diri manusia memiliki tiga dimensi, yaitu jasmaniah, psikologis, dan spiritual, dan bekerjasama secara

1 Clifford Geertz, Abangan, Santri, Priyayi dalam Masyarakat Jawa (Jakarta: Pustaka Jaya, 1983), hlm. 168.

${ }^{2}$ Deliar Noer, Pemikiran Politik Islam Santri (Jakarta: Panjimas, 1986), hlm. 5.

3 Dalam kehidupan budaya Islam, pengikut Islam tradisional masih mengadopsi paham-paham sinkretis dari paham Jawa (kejawen) dalam ritual keagamaannya.Oleh karena itu, praktek amalan dzikir ini hanya diamalkan oleh kalangan Islam tradisional dari lingkungan pesantren. (Lihat: Muhammad Abdullah, Fungsi Wirid dan Hizib dalam Sastra Lisan Pesantren, http://www.ilmukesehatan.com (diakses tanggal 8 Februari 2010). 
sinergis membentuk sistem sebagai satu kesatuan. Diantara ketiga dimensi tersebut, dimensi spirituAllah swt. yang memegang peran utama, karena hanya dimensi spiritual dengan dzikirlah yang mampu mengadakan kontak dengan Sang Pencipta. Dalam ajaran Islam, dzikir memiliki makna "mengingat nikmat Allah swt. swt. atau menyebut lafadh Allah swt. swt., bertahlil, bertahmid, bertasbih, ber-taqdis, bahkan termasuk membaca al-Qur'an dan membaca doa-doa". ${ }^{4}$

Allah swt. swt. mengingatkan kepada manusia untuk senantiasa berdzikir, karena dengan berdzikir akan membawa ketenangan dan dapat mengantarkan jiwa manusia tentram, bahkan lebih lanjut Allah swt. swt. menyeru kepada manusia untuk berdzikir karena seseorang yang lisannya selalu menyebut asma-asma Allah swt. dan hatinya ingat kepada Allah swt. maka ia selalu berada dalam lindungan dan bimbingan Allah swt.

Allah swt. berfirman dalam al-Quran surat ar-Ra'd ayat 28:

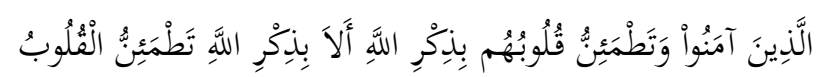

Artinya: "Orang-orang yang beriman hatinya menjadi tentram karena mengingat Allah swt., ketahuilah hanya dengan mengingat Allah swt. hati menjadi tentram."

berfirman:

Dalam surat al-Baqarah ayat 152 Allah swt. juga

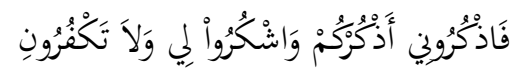

Artinya: "Maka mengingatlah kalian kepadaKu, niscaya Aku akan mengingat kalian......"

Menurut pengertian psikologi, dzikir sebagai suatu "daya jiwa kita yang dapat menerima, menyimpan, dan memproduksi kembali pengertian atau tanggapan kita". ${ }^{5}$

\footnotetext{
${ }^{4}$ Hasbi ash-Shiddieqy, al-Islam (Jakarta: Bulan Bintang , 1977), hlm. 566.

${ }^{5}$ M. Afif Anshori, Dzikir Demi Kedamaian Jiwa; Solusi Tasawuf atas Manusia Modern (Yogyakarta: Pustaka Pelajar, 2003), hlm 16.
} 
Aktifitas ini dalam agama Budha dan Hindu disinonimkan dengan meditasi ${ }^{6}$ dan semedi. ${ }^{7}$

Saat ini globalisasi dan modernisasi membawa berbagai kemudahan bagi manusia dalam menyelesaikan pekerjaan. Akibatnya, manusia seperti dininabobokan, terlena oleh kecanggihan teknologi. Keterlenaan ini membuat manusia menjadi lupa kepada Sang Pemberi Kemudahan, dan semakin mengikiskan sisi spiritual manusia. Nilai-nilai yang diakui kebenarannya menjadi semakin kabur. Bahkan memandang bahwa tradisi berdzikir yang dilakukan oleh kaum tarekat adalah sikap dan perilaku keagamaan yang kolot dan kuno, orang-orang modern selalu memandang sebelah mata terhadap tradisi berdzikir tersebut. Sehingga manusia mengalami kebingungan dalam memegang nilai kehidupan yang dapat menuntunnya dalam menghadapi kehidupan, dan akhirnya manusia menjadi rentan terhadap stress dan kegelisahan hidup.

${ }^{6}$ Dalam Kamus Besar Bahasa Indonesia, kata meditasi diartikan sebagai pemusatan pikiran dan perasaan untuk mencapai sesuatu. (Lihat: Tim Penyusun KBBI DEPDIKBUD, Kamus Besar Bahasa Indonesia (Jakarta: tp, 1988), hlm. 808). Dari segi etimologi, meditasi berasal dari bahasa Latin, meditatio, artinya hal bertafakur, hal merenungkan, memikirkan, mempertimbangkan, atau latihan, pelajaran persiapan. (Lihat: K. Prenc.m., et al, Kamus Latin Indonesia (Yogyakarta: Kanisius, 1969), hlm. 525). Sedangkan dari segi terminologi, meditasi adalah penggunaan pikiran secara terusmenerus untuk merenungkan beberapa kebenaran, misteri atau obyek penghormatan yang bersifat keagamaan sebagai latihan ibadah (Lihat: Soraya Susan Behbehani, The Messenger Within, terj. Cecep Ramli, Ada Nabi dalam Diri, Serambi Ilmu Semesta (Jakarta: tp, 2003), hlm. 26).

7 Semadi atau semedi adalah menghilangkan kehidupan jasad agar supaya seseorang dapat merasakan rahsaning gesang atau kehidupan sukma. Dengan sarana mengolah rasa disebut sirnaning papan lan tulis. Yakni jumeneng rasa jati yang benar-benar nyata, pasti dan weruh tanpa tuduh (menyaksikan sendiri tanpa referensi), atau menyaksikan "sesuatu" tanpa melibatkan badan wadag (akal-budi/rasio/pikiran/imajinasi/mata-wadag). Keberhasilannya dengan cara meredam gejolak nafsu jasadiah, dan dengan mengolah gerak-gerik anggota badan. (Lihat: http://www.Sabdalangit.wordpress. com/). 
Studi terbaru menjelaskan adanya korelasi antara semua sudut pandang Ilmu Psikologi dan ajaran Islam mengenai dimensi kejiwaan manusia. Berdasarkan dimensi kejiwaan yang dibahas secara utuh, gangguan kejiwaan terjadi karena hasrat spiritual yang tidak terpenuhi. Kehidupan modern saat ini yang lebih berorientasi kepada aspek fisik membuat manusia secara sadar atau tidak melupakan aspek spiritual yang ada di dalam dirinya. Dorongan ppiritual yang tidak terpenuhi inilah menyebabkan perasaan hampa dan tanpa makna yang berujung kepada terjadinya gangguan kejiwaan.

Dalam ajaran Islam, dzikir telah digunakan sebagai terapi gangguan kejiwaan sejak masa Rasulullah saw. Saat ini, terapi dzikir telah dibahas secara mendalam dan telah diakui sebagai suatu alternatif terapi yang sangat efektif dalam mengatasi gangguan kejiwaan. Kolaborasi antara psikoterapy berdasarkan teori psikologi dan ajaran Islam khususnya dzikir menghasilkan cabang psikoterapylogoterapy yang berorientasi kepada peningkatan makna hidup manusia secara kejiwaan dengan meningkatkan elemen spiritualitasnya. Logoterapy adalah sebuah sub bagian dari humanisme yang berwawasan transpersonal. Logoterapy sering dimasukkan pada Existential Psychiatri dan Humanistic Psychology, karena dianggap sebagai aliran psikologi yang telah mapan. Logoterapy menggunakan dzikir sebagai instrumennya, sesuai teori psikologi kondisi kejiwaan yang tenang karena berdzikir adalah suatu bentuk emosi positif karena dzikir berperan memenuhi kebutuhan dimensi spiritual manusia yang menyebabkan kehidupannya terasa bermakna.

\section{Teori Kejiwaan: Teori Kepribadian al-Ghazali dan Teori Humanistik Maslow.}

1. Teori Kepribadian al-Ghazali. 
al-Ghazali merupakan salah satu tokoh sufi yang hidup di tahun 1059-1111 M. Menurut Bastaman8, pandangan alGhazali mencakup berbagai ilmu pengetahuan yang mencakup asas-asas ilmiah (ada pemisahan secara tegas antara agama, filsafat, dan sains), sehingga layak dijadikan sebagai bahan kajian. Salah satu karyanya yang telah berumur lebih dari seribu tahun, adalah kitab Ihya' 'Ulumuddin, yang menjelaskan bahwa manusia mempunyai empat unsur, dan masing-masing unsur mempunyai unsur jasmani \& ruhani, yaitu:

1) Hati. al-Ghazali menjelaskan bahwa hati mempunyai dua pengertian. Secara jasmani, hati adalah sepotong daging yang terletak di bawah tulang rusuk sebelah kiri, yang di dalamnya terdapat lubang dan terdapat darah hitam sebagai sumber nyawa. Secara ruhani, hati tergolong halus, dikenal dengan istilah kalbu. Hati adalah hakikat manusia. Hati menjadi tempat manusia merasa, mengetahui, dan mengenal dari segi sifat kemanusiaan.

2) Ruh. Secara jasmaniah ruh adalah tubuh halus yang bersumber pada lubang hati. Dijelaskan dalam alQur'an", yaitu “...Dia menyempurnakannya dan meniupkan ke dalam (tubuh)-nya Ruh (ciptaan)-Nya....." Secara ruhani, hati merupakan tempat individu mengetahui dan merasa (feeling). Ruh adalah hati yang menikmati tingkat pandangan cahaya-cahaya Allah swt. Ruh menjadi tempat bagi Allah swt. untuk memperlihatkan perwujudannya tanpa tabir. Ruh merupakan kesatuan antara hasrat yang menjadi sifat batin dan tumbuh dari nafsu, dan kebajikan yang penuh kasih sayang yang menjadi sifat kalbu, serta cinta yang menjadi sifat ruh. Kesempurnaan ruh dan tempat semua pengetahuan bersemayam di kalbu. Akibatnya, kalbu menjadi tempat

\footnotetext{
${ }^{8}$ Hanna Jumhana Bastaman, Integrasi Psikologi dengan Islam: Menuju Psikologi Islami (Yogyakarta: Pustaka Pelajar, 1995), hlm. 76.

${ }^{9}$ al-Qur' an, as-Sajdah: 9.
} 
terlihatnya penyingkapan perwujudan ke-Tuhan-an dengan tingkat esensi yang berbeda, dan tempat penghubung antara alam ruhani (Allah swt.).

3) Nafsu. al-Ghazali menjelaskan bahwa nafsu mempunyai dua pengertian. Secara jasmani, nafsu merupakan penghimpun sifat tercela yang ada pada diri manusia, misalnya seks dan agresi yang bertempat di alam ketidaksadaran. Secara ruhani, nafsu merupakan diri manusia dengan berbagai sifatnya, sesuai dengan keadaannya. Apabila keadaan tenang, berada di bawah perintah ruh dan jauh dari goncangan syahwat. Pada kondisi demikian yang mendominasi adalah nafsu muthmainnah (jiwa yang tenang). Apabila ketenangan tidak sempurna, maka jiwa akan didorong oleh syahwat, dinamakan nafsu lawwamah (jiwa yang mencela). Apabila keadaan jauh dari sempurna, bahkan tunduk kepada perintah syahwat, dinamakan nafsu amarah.

4) Akal. Secara jasmani akal diartikan oleh al-Ghazali sebagai daya pikir atau potensi intelegensi, yaitu pengetahuan tentang hakikat segala keadaan atau sifatsifat ilmu. Secara ruhani, akal merupakan sifat ilmu yang memperoleh pengetahuan (hati itu sendiri= kalbu). Alam pikiran berhubungan erat dengan alam jasmani dalam kaitannya dengan koordinasi sistem dalam tubuh manusia. Alam pikiran juga berkaitan dengan batin karena kemampuannya mengkoordinasi nafsu, dan bekerjasama dengan kalbu di dalam alam ruhani menjadi suatu sistem yang mengatur sikap dan perilaku manusia. ${ }^{10}$ Akal merupakan dewan eksekutif yang memiliki kewenangan mengatur dan mengkoordinasi sistem kepribadian individu.

Masing-masing unsur yang ada pada pribadi individu mempunyai peran, dan bekerjasama secara sinergi, membentuk

${ }^{10}$ Hanna Jumhana Bastaman, Integrasi Psikologi dengan Islam..., hlm. 94. 
harmoni. Diantara keempat unsur yang dimiliki oleh pribadi, kalbu memegang peranan utama, karena kalbu merupakan raja bagi diri yang mempunyai penasehat, yaitu ruh. Nasehat yang diberikan ruh kepada kalbu, menjadi super ego bagi diri, yang senantiasa memberikan pertimbangan moral kepada ego. Nafsu menjadi rakyat bagi kalbu, dan bertugas melaksanakan setiap daulat kalbu. Nafsu memiliki prinsip kesenangan, karena itu nafsu senantiasa membujuk kalbu untuk mengunggulkan diri. Dalam usahanya membujuk kalbu, nafsu senantiasa memanfaatkan ego, untuk mempengaruhi akal yang berfungsi sebagai menteri yang selalu bermusyawarah dengan kalbu. Karena sifat kalbu yang selalu berubah inilah maka kalbu menjadi perebutan dominasi antara nafsu dan ruh.

\section{Teori Humanistik Maslow.}

Menurut Maslow, manusia pada dasarnya baik, dan memiliki potensi kreatif. Individu menjadi tidak baik dan tidak berbudaya, bukan karena faktor bawaan, melainkan karena pengaruh lingkungan. Manusia merupakan individu yang tidak pernah merasa puas. Kepuasan yang dialami manusia hanyalah bersifat sementara, karena manusia mempunyai kecenderungan untuk selalu memenuhi kebutuhannya. ${ }^{11}$

Kebutuhan manusia disusun Maslow ke dalam lima kebutuhan yang bertingkat, yaitu: a. Kebutuhan fisiologis. Kebutuhan fisiologis merupakan kebutuhan manusia yang paling dasar. Kebutuhan fisiologis berhubungan dengan kebutuhan yang paling mendesak pemuasannya, karena berkaitan dengan pemeliharaan biologis dan kelangsungan hidup; b. Kebutuhan akan rasa aman. Kebutuhan akan rasa aman, merupakan kebutuhan yang mendorong individu untuk memperoleh ketentraman, kepastian, dan keteraturan dari lingkungan; c. Kebutuhan akan cinta dan memiliki. Kebutuhan akan cinta dan memiliki merupakan kebutuhan yang mendorong manusia untuk mengadakan ikatan emosional

${ }^{11}$ Koeswara. E, Teori-Teori Kepribadian (Bandung: Eresco, 1986), hlm. 118-125. 
dengan orang lain; d. Kebutuhan akan harga diri, berupa: 1) Penghormatan atau penghargaan pada diri sendiri, semisal hasrat untuk memperoleh kompetensi, rasa percaya diri, kekuatan pribadi, adekuasi, kemandirian, dan kebebasan; 2) Penghormatan dan penghargaan dari orang lain, semisal prestasi; dan e. Kebutuhan akan aktualisasi diri. Kebutuhan akan aktualisasi diri adalah kebutuhan untuk memenuhi hasrat individu menjadi diri yang sesuai dengan keinginan dan potensi yang dimiliki.

Individu yang terpenuhi kebutuhan aktualisasi dirinya mempunyai ciri-ciri: ${ }^{2}$ a) Mengamati realitas secara efisien. Individu dalam mengamati realitas bersikap apa adanya, tanpa dicampuri keinginan atau harapan, kecemasan, prasangka, optimisme atau pesimisme yang keliru; b) Penerimaan diri sendiri, orang lain, dan kodrat. Individu mampu menerima kekurangan dan kelemahan diri, orang lain, dan lingkungan dengan penuh kerelaan; c) Spontan, sederhana, dan wajar. Sikap spontan, sederhana dan wajar bersumber dari dalam pribadinya. Individu akan patuh pada peraturan-peraturan yang bisa melindungi diri dan sesamanya dari kesakitan dan ketidakadilan; d) Terpusat pada masalah. Individu akan terlibat secara mendalam pada tugas, pekerjaan, atau misi yang dianggap penting, maksudnya individu lebih berorientasi pada masalah-masalah yang melampaui kebutuhan mereka sendiri, bukan pada sikap egosentris; e) Pemisahan diri dan kebutuhan privasi. Pada pergaulan sosial, individu sering dianggap memisahkan diri, sombong dan dingin. Anggapan ini lebih diakibatkan oleh kemampuan individu dalam memandang persahabatan sebagai suatu hubungan yang lebih mendalam; f) Kemandirian. Individu lebih bergantung pada kemampuan diri sendiri daripada orang lain dalam hal kepuasan; g) Kesegaran dan apresiasi. Individu akan menghargai hal-hal pokok dalam kehidupan dengan rasa kagum, gembira, dan bahkan heran; h)

12 Ibid. hlm. 138-146. 
Pengalaman puncak atau pengalaman mistik. Pengalaman puncak menurut Maslow, menunjuk pada momen-momen dari perasaan yang mendalam dan meningginya tegangan seperti yang dihasilkan oleh relaksasi dan orgasme seks; i) Minat Sosial. Individu mempunyai ikatan perasaan yang mendalam dengan sesamanya; j) Hubungan antarpribadi. Individu mempunyai hubungan antarpribadi lebih mendalam, dan cenderung membangun hubungan yang dekat dengan orang-orang yang memiliki kesamaan karakter, kesanggupan, dan bakat; $\mathrm{k}$ ) Karakter demokratis. Individu mempunyai kebebasan berprasangka dan cenderung menaruh hormat pada semua orang; 1) Perbedaan antara cara dan tujuan. Individu biasanya terpusat pada tujuan; m) Rasa humor yang filosofis. Individu biasanya menyukai humor yang mengekspresikan akan kebodohan dan kecurangan manusia; n) Kreativitas. Kreatifitas bagi individu yang telah teraktualisasi, merupakan suatu tindakan yang asli, naif, dan spontan; o) Penolakan enkulturasi. Individu biasanya berani membuat keputusan sendiri, sekalipun bertentangan dengan pendapat umum.

\section{Makna Hidup Secara Kejiwaan}

Manusia merupakan makhluk paling sempurna diantara makhluk ciptaan Allah swt. Namun kesempurnaan itu pun masih harus diperjuangkan oleh manusia. Perjuangan yang harus dilakukan seumur hidup dengan istiqamah (kekuatan tekad dan keyakinan), kerinduan, dan kecintaan yang tulus dan menggebu terhadap Allah swt. dengan tanpa mengabaikan keseimbangan "laku" berpikir dan berdzikir, dan keseimbangan dalam beribadah secara vertikal dan horisontal.

Filsafat manusia yang mendasari semangat untuk hidup autentik guna mencapai kebebasan lewat upaya untuk hidup bermakna. Fisafat logoterapy mengisyaratkan tentang harapan besar mengenai masa depan kehidupan manusia yang lebih berharga dan bermakna. Teori tentang kodrat manusia dalam filsafat manusia dibangun atas tiga asumsi dasar, yang saling 
menopang satu dan yang lainnya: a) Kebebasan bersikap dan; b) Kehendak untuk hidup bermakna; dan c) Makna hidup.

Hidup bermakna, merupakan motivasi utama yang terdapat pada manusia untuk mencari, menemukan, memenuhi tujuan dan arti hidup. Kesenangan bukanlah semata-mata tujuan hidup manusia, melainkan akibat sampingan (by product) dari sebuah tujuan itu sendiri. Begitu juga dengan sarana untuk mencapai tujuan, bekal mencapai tujuan itu sendiri. Karena pada dasarnya pleasure dan power sebenarnya sudah tercakup dalam the will to meaning (kekuasaan merupakan sarana untuk mencapai makna hidup dan kesenangan merupakan efek samping yang dihasilkan dari terpenuhinya makna hidup tersebut).

Makna hidup bersifat unik, spesifik, personal, sehingga masing-masing orang mempunyai makna hidup yang khas dan cara penghayatan yang berbeda antara pribadi yang satu dengan yang lainnya. Kegiatan untuk membimbing, melakukan kegiatan yang secara potensial mengandung nilai-nilai yang memungkinkan seseorang untuk menemukan makna hidup, antara lain : a) Berkarya serta melakukan tugas hidup sebaikbaiknya, disebut creative values (nilai-nalai kreatif ); b) Berusaha mengalami dan menghayati setiap nilai yang ada dalam kehidupan itu sendiri, disebut experiental values (nilai-nilai penghayatan); dan c) Menerima berbagai bentuk penderitaan yang tidak mungkin dielakkan lagi, seperti kedukaan, sakit yang tak bisa sembuh, kematian, setelah segala upaya telah dilakukan secara maksimal, yang disebut sebagai attitude values. ${ }^{13}$

Hidup adalah sebuah perjalanan yang berujung kepada kematian. Kematian adalah puncak dari kehidupan di dunia, dan akan diteruskan dalam kehidupan di akhirat yang kekal. Untuk itu diperlukan jalan untuk kebahagiaan di dunia dan akhirat kelak berupa thariqah. Esensi thariqah telah

${ }^{13}$ http:// www.psikologimania.com. (diakes pada Februari 2012). 
diteladankan oleh Rasulullah saw. Thariqah menurut Syakir adalah jalan. ${ }^{14}$

Jalan yang dimaksud adalah jalan sebagai media dari syari'at menuju hakikat yang pada akhirnya akan menghantarkan individu pada ma'rifat. Perjalanan dan perjuangan manusia dalam mencapai kesempurnaan merupakan metamorfosis manusia dari manusia sebagai makhluk yang memiliki kecenderungan merusak menjadi makhluk dengan kecenderungan memelihara. Perjalanan dan perjuangan yang ditempuh melalui thariqah yang lurus yaitu "shiraathal mustaqiim"15 yang hanya bisa diperoleh dengan petunjuk Allah swt., yaitu agama.

\section{Dzikir merupakan Tradisi di Pesantren}

Ciri khas pesantren tradisional yang tersebar di pelosok nusantara pada umumnya menganut sistem nilai ahli sunnah waljamaah dan sebagai lembaga pendidikan dan pengajaran agama Islam. Namun, ada juga yang lebih menonjolkan pada upaya pengembangan ajaran tasawuf yang bersifat praktis (tarekat), baik yang diamalkan secara individual maupun berjamaah dengan para santrinya di pesantren. ${ }^{16}$

14 Dr. Syakir Abdul Jabbar, Metode Ilmiah bagi Suatu Akidah, terj. Abd. Qadir Hamid (Jakarta: Duaputra Press, 2001), hlm. 4.

${ }^{15}$ al-Qur'an, al-Fatihah [1]: 7.

16 Di lingkungan internal pesantren, para santri (jamaah) beserta kyai mengamalkan dzikir secara rutin. Diantara pesantren yang berfungsi sebagai pusat kegiatan tasawuf praktis (tarekat) ada yang lebih mengkhususkan diri pada pengembangan bidang tasawuf sebagai inti pengajarannya, namun lebih terbatas pada segi praktisnya saja, sedangkan segi pemikiran kontemplatifnya sangat kurang. (Lihat: Yasmadi, Modernisasi Pesantren: Kritik Nurcholish Madjid terhadap Pendidikan Tradisional (Jakarta: Ciputat Press, 2002), hlm. 103. Zaenal Abidin, Dzikir Suatu Tradisi Pesantren Menuju Terapeutik Depresif (Kajian Menuju Terapi Psikosomatik dan Neurosis), Jurnal Studi Islam \& Budaya P3M STAIN Purwokerto, Vol. 4, No. 1 (Januari-Juni 2006). 
Sebuah tarekat biasanya memilki serangkaian teknik spiritual dan praktik ibadah yang khas, dan yang paling menonjol dari semua ibadah tersebut adalah dzikir (yang disyari'atkan al-Quran dan Sunnah Rasulullah saw.), yang berisi pembacaan nama-nama Allah swt. dan kalimat "Lailaha Illallah" dengan cara yang khas pula dan jumlahnya pun tidak ditentukan". ${ }^{17}$

Bahkan, kadangkala ada yang disertai dengan berbagai rangkaian doa (hizib), shalawat, dan gerakan-gerakan tubuh tertentu yang ritmik dan estetis, dan ada juga diikutkan amalanamalan asketiknya. Hampir semua kyai di pesantren tarekat menjadi imam tetap di masjidnya, maka umumnya mereka memimpin masyarakat dalam melaksanakan sembahyang di masjid, dan memimpin jamaah melakukan dzikir sesudah sembahyang wajib. Dalam pelaksanaan dzikir ini, ayat-ayat tertentu dipilih dan diucapkan bersama-sama dan asmaul husna diucapkan berulang-ulang.

Hasil penelitian terhadap berbagai pesantren kategori aliran tarekat, diketahui bahwa para santri atau jamaah secara bersama-sama melaksanakan dzikir rutin di bawah pimpinan Kyai. Bentuk dzikir dan rumusan nama-nama Allah swt. yang diucapkan tidaklah jauh berbeda dengan yang dipraktikkan oleh jamaah tarekat di pesantren pada umumnya. Individuindividu ataupun jamaah tarekat yang mengikuti kegiatan dzikir tersebut pada dasarnya karena ingin lebih mendekatkan diri dan mencari ridha Allah swt. sebagai jalan menuju surga yang senantiasa menjadi idamannya. ${ }^{18}$

\section{Makna Dzikir}

17 Martin Van Bruinessen, Kitab Kuning: Pesantren dan Tarekat (Bandung: Mizan, 1995), hlm. 263.

18 Zamakhsyari Dhofier, Tradisi Pesantren: Studi tentang Pandangan Hidup Kyai (Jakarta: LP3ES, 1982), hlm. 136. 
Secara etimologi, dzikir mempunyai arti mengingat, memperhatikan, mengenang, mengambil pelajaran, mengenal atau mengerti dan ingatan. Ensiklopedi Islam menjelaskan bahwa istilah dzikir memiliki multi interpretasi, diantara pengertian-pengertian dzikir adalah menyebut, menuturkan, mengingat, menjaga, atau mengerti perbuatan baik. ${ }^{19}$

Sedangkan dzikir dalam arti menyebut nama Allah swt. yang diamalkan secara rutin, biasanya disebut wirid atau aurad. Dan amalan ini termasuk ibadah murni (mahdhah), yaitu ibadah yang langsung berhubungan dengan Allah swt. Sebagai ibadah mahdhah maka dzikir jenis ini terikat dengan norma-norma ibadah langsung kepada Allah swt. yaitu harus ma'tsur (ada contoh atau perintah dari Rasulullah saw.).

Secara terminologi definisi dzikir banyak sekali. Ensiklopedi Nasional Indonesia menjelaskan dzikir adalah ingat kepada Allah swt. dengan menghayati kehadiranNya, keMaha SucianNya, keMaha keTerpujianNya dan keMaha BesaranNya. Dzikir merupakan sikap batin yang bisa diungkapkan melalui ucapan Tahlil (La Ilaha illa Allah artinya Tiada Tuhan Selain Allah swt.), Tasbih (Subhana Allah artinya Maha Suci Allah swt.), Tahmid (Alhamdulillah, artinya Segala Puji Bagi Allah swt.), dan Takbir (Allahu Akbar, artinya Allah Maha Besar). Dalam Shorter Ensiklopedi of Islam, dzikir dalam hati (bi al-qalbu) dan dengan lisan (bi al-lisan) adalah penyebut, dimana keduanya berhubungan, sebagai cara yang khusus, penyembahan kepada Allah swt. dengan bentuk tertentu yang pasti, diajarkan dalam

19 In'am Muzahiddin Masyhudi, Nurul Wahyu A., Berdzikir dan Sehat ala Ustadz Haryono (Semarang: Syifa Press, 2006), hlm. 7. Dalam kehidupan manusia unsur "ingat" ini sangat dominan adanya, karena merupakan salah satu fungsi intelektual. Menurut pengertian psikologi, dzikir (ingatan) sebagai suatu "daya jiwa kita yang dapat menerima, menyimpan dan memproduksi kembali pengertian atau tanggapan-tanggapan kita". (Lihat: M. Afif Anshori, Dzikir ..., hlm. 16. 
suatu perintah agama, bisa keras bisa dalam hati, dengan pernafasan khusus dan gerakan jasmani. ${ }^{20}$

Dari pengertian di atas, makna dzikir sesuai yang dijelaskan oleh hadits-hadits Nabi saw. tentang dzikir yang mencakup doa, mengucapkan asma al-husna, membaca alQur'an, tasbih (mensucikan Allah swt.), tahmid (memuji Allah swt.), takbir (mengagungkan Allah swt.), tahlil (meng-Esakan Allah swt.), istighfar (memohon ampunan kepada Allah swt.), hawqalah (mengakui kelemahan diri).

Secara umum dzikir dibagi menjadi dua macam, yaitu dzikir dengan hati dan dzikir dengan lisan. Masing-masing dari keduanya terbagi pada dua arti, yaitu: dzikir yang berarti ingat dari yang tadinya lupa, dan dzikir dalam arti kekal ingatannya. Sedangkan yang dimaksud dengan dzikir lisan dan hati adalah sebagai berikut: a). Dzikir dengan lisan berarti menyebut nama Allah swt., berulang-ulang kali, sifat-sifatNya berulang-ulang kali pula atau pujian-pujian kepadaNya. Untuk dapat kekal dan senantiasa melakukannya, hendaknya dibiasakan atau dilaksanakan berkali-kali atau berulang-ulang kali; dan b). Dzikir kepada Allah swt. dengan hati, ialah menghadirkan kebesaran dan keagungan Allah swt. di dalam diri dan jiwanya sendiri sehingga mendarah daging.

Menurut ahli tasawuf, dzikir itu terbagi menjadi tiga bagian, yaitu: 1). Dzikir lisan atau disebut juga dzikir nafi isbat, yaitu ucapan La Ilaaha Illallah. Pada kalimat ini terdapat hal yang menafikan yang lain dari Allah swt. dan mengisbatkan Allah swt.. Dzikir nafi isbat ini dapat juga disebut dzikir yang nyata karena ia diucapkan dengan lisan secara nyata, baik dzikir bersama-sama maupun dzikir sendirian; 2). Dzikir kalbu atau hati, disebut juga dzikir: Asal dan kebesaran, ucapannya Allah swt. Dzikir kalbu ini dapat juga disebut dzikir ismu dzat karena ia langsung berdzikir dengan menyebut nama Dzat; dan 3). Dzikir sir atau rahasia, disebut juga dzikir isyarat dan nafas,

${ }^{20}$ Ibid. hlm. 7- 8 
yaitu berbunyi: Hu. Dzikir ini adalah makanan utama sir (rahasia). Oleh karena itu ia bersifat rahasia, maka tidaklah sanggup lidah menguraikannya, tidak ada kata-kata yang dapat melukiskannya. ${ }^{21}$

Fadhilah dzikir banyak ditemukan di dalam al-Qur'an, banyak sekali ayat-ayat yang menyuruh kita untuk berdzikir kepada Allah swt. atau menganjurkan orang supaya berdzikir dan menyatakan tentang keutamaan berdzikir kepada Allah swt. Demikian pula dengan hadits-hadits Nabi saw. tentang keutamaan berdzikir kepada Allah swt. ${ }^{22}$ Dzikrullah adalah amalan yang sangat tinggi nilainya dan sangat mulia dalam pandangan Allah swt. Dzikrullah juga menjadi pembeda antara orang yang dikasihi oleh Allah swt. dan orang yang dibenciNya. Betapa mulianya bila seseorang mampu selalu mengingat Allah swt. dalam dzikirnya. Orang yang berdzikir akan diingat Allah swt. bahkan dalam diri Allah swt. sendiri. ${ }^{23}$ Salah satu ayat dalam al-Qur'an Allah swt. berfirman yang artinya: "orang-orang yang beriman hatinya menjadi tentram karena mengingat Allah swt., ketahuilah hanya dengan mengingat Allah swt. hati menjadi tentram". ${ }^{24}$

Berikut ini manfaat dzikir yang berhubungan dengan kesehatan mental: 1). Menghilangkan segala kerisauan dan kegelisahan serta mendatangkan kegembiraan dan kesenangan; 2). Mendatangkan wibawa dan ketenangan bagi pelakunya; 3). Mengilhamkan kebenaran dan sikap istiqamah dalam setiap urusan; 4). Dzikir adalah makanan rohani sebagaimana nutrisi bagi tubuh manusia, dzikir juga merupakan perangkat yang membuat kalbu bersih dari karat yang berupa lalai dan mengikuti hawa nafsu; 5). Dzikir juga

${ }^{21}$ Moh Saefullah al-aziz, Risalah Memahami Ilmu Tasawwuf (Surabaya: Terbit Terang, 1978), hlm. 194 -195.

22 Ibid. hlm. 180.

23 M. Aziz Amin, Tirmidzi Abdul Majid, Analisa Dzikir da Doa (Jakarta: Pinbuk Press, 2004), hlm. 19-21.

24 al-Qur'an, Ar-Ra'd: 28. 
menjadi penyebab turunnya sakinah (ketenangan), penyebab adanya naungan para malaikat, serta penyebab datangnya limpahan rahmat, dan itulah nikmat yang paling besar bagi seorang hamba; 6). Menghalangi lisan seorang hamba melakukan ghibah, berkata dusta, dan melakukan perbuatan buruk lainnya; 7). Orang yang berdzikir akan membuat teman duduknya tentram dan bahagia; 8). Orang yang berdzikir akan diteguhkan kalbunya, dikuatkan tekadnya, dijauhkan dari kesedihan, dari kesalahan, dari setan dan tentaranya. Selain itu kalbunya akan didekatkan pada akhirat dan dijauhkan dari dunia; 9). Apabila kelalaian merupakan penyakit, dzikir merupakan obat baginya. Ada ungkapan bahwa "Jika kami sakit, kami berobat dengan dzikir. Namun kadangkala kami lalai, hingga iapun kambuh lagi"; 10) Memudahkan pelaksanaan amal saleh, mempermudah urusan yang pelik, membuka pintu yang terkunci, serta meringankan kesulitan; 11) Memberi rasa aman kepada mereka yang takut sekaligus menjauhkan bencana; dan 12). Dzikir menghilangkan rasa dahaga di saat kematian tiba sekaligus memberi rasa aman dari segala kecemasan. ${ }^{25}$

Dzikir memegang peranan penting dalam proses penyucian jiwa (tazkiyyat al-nafs). ${ }^{26}$ Dalam Islam, mengucapkan lafadz dzikir yang identik dengan syahadat atau tahlil, merupakan legitimasi bahwa orang tersebut rela menjadi muslim, sekaligus mukmin. Pengucapan ini bukan hanya sekedar di mulut saja, melainkan di resap dalam sanubari dengan meyakini bahwa "tiada Tuhan selain Allah swt". Dzikir merupakan aktivitas religius penting bagi para sufi, untuk

\footnotetext{
${ }^{25}$ M. Aziz Amin, Tirmidzi Abdul Majid, Analisa Dzikir, hlm. 22-26.

${ }^{26}$ Mensucikan jiwa adalah tujuan utama yang ingin dicapai agama di atas dunia ini. Kesucian jiwa merupakan kesempurnaan manusia dan keluhuran rohani, maka hanya dengan jiwa yang suci yang akan mampu mengantarkan pada martabat manusia sempurna. (Lihat: Abdul Halim Mahmud, Terapi dengan Dzikir; Mengusir Kegelisahan \& Merengkuh Ketenangan Jiwa (Jakarta: PT. Mizan Publika, 2004).
} 
mengembangkan diri agar berada sedekat mungkin dengan Allah swt. ${ }^{27}$

\section{Logoterapy: Psikoterapi melalui Dzikir Menuju Kebermaknaan Hidup}

Sistem dan metode psikoterapi pada dasarnya berlandaskan pada filsafat manusia yang khas. Setiap model psikoterapi yang berusaha mengembalikan kebebasan manusia sebagai suatu yang kodrati, pastilah akan bersinggungan dengan kedua mahzab dalam psikologi.Selain itu, terapi dapat disesuaikan dengan kebutuhan, dengan memperhatikan aspekaspek psikology user (pengguna/pasien). Misalnya latar belakang, agama dan kepercayaan, pandangan hidup, budaya, dan lain-lain. Aspek psikologis ini banyak yang bersimbiosis dengan teori-teori dasar psikologi yang menghasilkan terapi yang sangat beragam, salah satunya adalah logoterapy atau terapi peningkatan makna hidup yang merupakan sub bagian dari Ilmu Psikologi Humanisme yang berwawasan transpersonal. ${ }^{28}$

Logoterapy diperkenalkan oleh Viktor Frankl29, seorang dokter ahli penyakit saraf dan jiwa. Logoterapy berasal dari kata logos yang dalam Bahasa Yunani berarti makna dan juga rohani, sedangkan terapi adalah penyembuhan atau pengobatan.

${ }^{27}$ In'am Muzzahiddin Masyhudi, Nurul Wahyu Arvitasari, Berdzikir, hlm. 1.

28 Disadur dari http://psychologymania.wordpress.com. LogoterapySebuah Pendekatan Hidup Bermakna (diakses tanggal 11 Juli 2011).

${ }^{29}$ Viktor Emil Frankl (lahir 26 Maret1905, meninggal 2 September1997 pada umur 92 tahun) adalah seorang neurolog dan psikiaterAustria serta korban Holocaust yang selamat. Frankl adalah pendiri logoterapy dan Analisis Eksistensial "Aliran Wina Ketiga" dalam psikoterapi. Bukunya, Man's Search for Meaning (pertama kali terbit pada 1946) mencatat pengalamannya sebagai seorang tahanan kamp konsentrasi dan menguraikan metode psikoterapisnya dalam upaya mencari makna dalam segala bentuk keberadaan, bahkan yang paling kelam sekalipun, dan dengan demikian juga alas an untuk tetap hidup. Frankl adalah salah satu tokoh utama dalam terapieksistensial.(Dikutip: http://www.wikipedia.org/wiki/Viktor_Frankl) 
Logoterapy secara umum dapat digambarkan sebagai corak psikologi atau psikiatri yang mengakui adanya dimensi kerohanian pada manusia di samping dimensi ragawi dan kejiwaan, serta beranggapan bahwa makna hidup (the meaning of life) dan hasrat untuk hidup bermakna (the will of meaning) merupakan motivasi utama manusia guna meraih taraf kehidupan bermakna (the meaningful life) yang didambakannya.

Ada tiga asas utama logoterapy yang menjadi inti dari terapi ini, yaitu: 1) Hidup itu memiliki makna dalam setiap situasi, bahkan dalam penderitaan dan kepedihan sekalipun. Makna adalah sesuatu yang dirasakan penting, benar, berharga dan didambakan serta memberikan nilai khusus bagi seseorang dan layak dijadikan tujuan hidup; 2) Setiap manusia memiliki kebebasan untuk menentukan sendiri makna hidupnya. Dari sini kita dapat memilih makna atas setiap peristiwa yang terjadi dalam diri kita, apakah itu makna positif atupun makna yang negatif. Makna positif inilah yang dimaksud dengan hidup bermakna; dan 3) Setiap manusia memiliki kemampuan untuk mangambil sikap terhadap peristiwa tragis yang tidak dapat dielakkan lagi yang menimpa dirinya sendiri dan lingkungan sekitar.

Ketiga asas itu tercakup dalam ajaran logoterapy mengenai eksistensi manusia dan makna hidup sebagai berikut: a). Dalam setiap keadaan, termasuk dalam penderitaan sekalipun, kehidupan ini selalu mempunyai makna; b). Kehendak untuk hidup bermakna merupakan motivasi utama setiap orang; c). Dalam batas-batas tertentu manusia memiliki kebebasan dan tanggung jawab pribadi untuk memilih, menentukan dan memenuhi makna dan tujuan hidupnya; dan d). Hidup bermakna diperoleh dengan jalan merealisasikan tiga nilai kehidupan, yaitu nilai-nilai kreatif, nilai-nilai penghayatan dan nilai-nilai bersikap.

Tujuan logoterapy adalah agar setiap pribadi mampu: 1). Memahami adanya potensi dan sumber daya rohaniah yang secara universal ada pada setiap orang terlepas dari ras, 
keyakinan dan agama yang dianutnya; 2). Menyadari bahwa sumber-sumber dan potensi itu sering ditekan, terhambat dan diabaikan bahkan terlupakan; 3). Memanfaatkan daya-daya tersebut untuk bangkit kembali dari penderitaan untuk mampu tegak kokoh menghadapi berbagai kendala, dan secara sadar mengembangkan diri untuk meraih kualitas hidup yang lebih bermakna.

Pandangan logoterapy terhadap manusia adalah: a). Menurut Frankl manusia merupakan kesatuan utuh dimensi ragawi, kejiwaan dan spiritual; b). Frankl menyatakan bahwa manusia memiliki dimensi spiritual yang terintegrasi dengan dimensi ragawi dan kejiwaan. Perlu dipahami bahwa sebutan spiritual dalam logoterapy tidak mengandung konotasi keagamaan karena dimensi ini dimiliki manusia tanpa memandang ras, ideologi, agama dan keyakinannya; c) Dengan adanya dimensi spiritual ini manusia mampu melakukan dengan sadar mengambil jarak terhadap dirinya serta mampu meninjau dan menilai dirinya sendiri; dan d). Manusia adalah makhluk yang terbuka terhadap dunia luar serta senantiasa berinteraksi dengan sesama manusia dalam lingkungan sosialbudaya serta mampu mengolah lingkungan fisik di sekitarnya.

Kerangka pikir teori kepribadian model logoterapy dan dinamika kepribadiannya dapat digambarkan sebagai berikut: "Setiap orang selalu mendambakan kebahagiaan dalam hidupnya. Dalam pandangan logoterapy kebahagiaan itu tidak datang begitu saja, tetapi merupakan akibat sampingan dari keberhasilan seseorang memenuhi keinginannya untuk hidup bermakna. Mereka yang berhasil memenuhinya akan mengalami hidup yang bermakna dan ganjaran dari hidup yang bermakna adalah kebahagiaan. Di lain pihak mereka yang tak berhasil memenuhi motivasi ini akan mengalami kekecewaan dan kehampaan hidup serta merasakan hidupnya tidak bermakna. Selanjutnya akibat dari penghayatan hidup yang hampa dan tak bermakna yang berlarut-larut tidak teratasi dapat mengakibatkan gangguan kejiwaan". 
Eksistensi manusia menurut pandangan logoterapy: 1). Memiliki kebebasan berkendak. Dalam pandangan logoterapy manusia memilki kebebasan untuk menentukan sikap terhadap kondisi psikologis, sosiokultural dan kesejarahannya. Kemampuan inilah yang menyebabkan manusia memiliki kebebasan untuk menentukan apa yang dianggap penting dan baik bagi dirinya. Kebebasan ini dalam pandangan logoterapy harus diimbangi dengan tanggung jawab agar tidak berkembang menjadi kesewenangan; 2). Memiliki kehendak untuk hidup bermakna. Hasrat untuk dapat hidup inilah yang memotivasi individu untuk bekerja, berkarya dan melakukan kegiatan penting dengan tujuan agar hidupnya menjadi berharga dan dihayati secara bermakna; dan 3). Memiliki makna hidup.

Makna hidup menurut Victor Frankl memiliki karakteristik: a). Makna hidup itu bersifat unik dan personal, artinya makna hidup seseorang itu bersifat khusus, berbeda dengan orang lain, dan berubah dari waktu ke waktu; b). Makna hidup itu bersifat spesifik dan konkrit, artinya dapat ditemukan dalam pengalaman dan kehidupan nyata sehari-hari dan tidak selalu harus dikaitkan dengan tujuan-tujuan idealistis, prestasiprestasi akademis yang tinggi atau hasil renungan filosofis yang kreatif; dan c). Makna hidup itu bersifat memberi pedoman dan arah terhadap kegiatan yang dilakukan sehingga makna hidup seakan-akan menantang individu untuk memenuhinya. Dalam pandangan logoterapy makna hidup adalah "bertanggungjawab terhadap hidupnya karena sikap bertanggung jawab merupakan esensi dasar kehidupan manusia".

Inti ajaran logoterapy ada empat, yaitu: 1). Dalam setiap keadaan apapun selalu memiliki makna; 2). Kehendak akan hidup bermakna merupakan motivasi utama hidup; 3). Dalam batasan tertentu, manusia memiliki kebebasan untuk memilih, menentukan dan memenuhi tujuan hidupnya; dan 4). Hidup bermakna diperoleh dengan merealisasikan tiga nilai, yaitu: a). Tidak mesti sama dengan orang lain; b). Nilai-nilai 
penghayatan; dan c). Nilai-nilai sikap dan perilaku harus tahu apa landasannya.

Cara untuk mendapat dan menentukan makna hidup: a). Menunjukkan segala sesuatu yang secara berpotensi bermakna, namun untuk menentukan apa yang dianggap bermakna, hal itu terpulang pada individu itu sendiri; b). Menunjukkan sumber-sumber makna hidup; dan c). Membantu agar individu lebih menyadari tanggungjawab pribadi dalam memenuhi apa yang harus dicapai dan kewajiban yang harus ditunaikan.

Metode logoterapy boleh dibuat disesuaikan dengan keperluan, dengan mengambil aspek-aspek psikology user (pengguna/pesakit). Misalnya latar belakang, agama dan kepercayaan, pandangan hidup, budaya, dan lain-lain. Aspek psikologi ini banyak yang bersimbiosis dengan teori dasar psikologi yang menghasilkan terapi. Dzikir sebagai salah satu ibadah yang diajarkan dalam Islam juga mempunyai urgensi yang sangat tinggi terhadap penanganan gangguan kejiwaan seseorang khususnya umat muslim yang dikenal dengan terapi dzikir.

Kunci keberhasilan dari terapi dzikir, ${ }^{30}$ yaitu: 1). Perasaan yang ikhlas kepada Sang Pencipta yaitu Allah swt.; 2). Memiliki keyakinan bahwa tidak ada satu pun ciptaan Allah swt. Di dunia ini yang boleh mengalahkan Allah swt. yang menciptakannya; dan 3). Memiliki keyakinan bahwa manusia ciptaan Allah swt. yang mulia.

Proses tahap model terapi dzikir, ialah: a). Pilihlah posisi duduk yang selesa, seperti duduk di kursi, besila, namun bila sedang sakit ambil posisi tiduran atau seperti saat shalat; $b$ ). Tenangkan diri sampai benar-benar selesa; c). Lalu mulailah menyebutkan kata atau kalimat dalam hati dengan tenang secara perlahan, sesuaikan dengan keyakinan yang dimiliki, misalnya duduk besila dengan berdzikir.

30 Disadur dari http://www.detikislam.blogspot.com.Psikologi, Jenis-Jenis Terapi Dalam Islam (diakses tanggal 2 Agustus 2011). 
Setelah beberapa waktu, sambil tetap model dzikir mulailah melakukan teknik nafas: 1). Tarik nafas perlahan; 2). Buang nafas melalui mulut sebanyak-banyaknya sampai posisi kita membongkok tentu jika anda memilih posisi duduk atau posisi bersujud, jika anda memilih posisi duduk shalat usahakan dahinya menyentuh lantai. Terus buang nafas sampai perut dan paru-paru sangat kempis. Dalam posisi sujud dengan kepala tetap menyentuh lantai, boleh menahan nafas beberapa saat; 3).Terus lakukan a dan b sampai benar-benar merasa lega.

Dzikir dalam mengingat Allah swt. sebaiknya dilakukan setiap saat, baik secara lisan maupun dalam hati. Artinya kegiatan apapun yang dilakukan oleh seorang muslim sebaiknya jangan sampai melupakan Allah swt. Dimanapun seorang muslim berada, sebaiknya selalu ingat kepada Allah swt. sehingga akan menimbulkan cinta beramal saleh kepada Allah swt. serta malu berbuat dosa dan maksiat kepadaNya.

Karena dzikir dilakukan oleh lisan dan hati, maka kerjasama antara lisan dan hati dalam hal dzikir ini sangatlah baik, sebab bilamana seseorang telah mengamalkan dan melakukan dengan disiplin, dengan sendirinya akan meningkat menjadi dzikir $a^{\prime} d h a^{\prime} a$, artinya seluruh badannya akan terpelihara dari berbuat maksiat kepada Allah swt. Bagi orang yang hatinya telah bening dan jernih akan dapat mengontrol anggota badannya untuk tetap disiplin, ucapannya akan sesuai dengan perbuatannya, lahiriyahnya akan sesuai dengan batiniyyahnya. ${ }^{31}$

Dzikir ditinjau dari sudut Ilmu Kedokteran kontemporer, pengucapan "Laa Ilaaha Illallah" dan "Astaghfirullah" dapat menghilangkan nyeri dan bisa menumbuhkan ketenangan serta kestabilan saraf. Sebab dalam kedua bacaan dzikir tersebut terdapat huruf jahr32 yang dapat mengeluarkan $\mathrm{CO}_{2}$ dari otak.

\footnotetext{
${ }^{31}$ Moh. Saefullah al-aziz, Risalah, hlm. 193-194.

$32 \mathrm{Jahr}$ menurut bahasa adalah jelas.Sedangkan menurut istilah, jahr adalah tertahannya aliran atau hembusan napas ketika mengucapkan huruf, karena
} 
Dalam kalimat "Laa Ilaaha Illallah" terdapat huruf jahr yang diulang tujuh kali, yaitu huruf "Lam", dan "Astaghfirullah" terdapat huruf "Ghayn", "Ra", dan dua buah "Lam" sehingga ada empat huruf jahr yang harus dilafalkan keras sehingga kalimat dzikir tersebut akan mengeluarkan $\mathrm{CO}_{2}$ lebih banyak saat udara dihembuskan keluar mulut. Dan $\mathrm{CO}_{2}$ yang dikeluarkan oleh tubuh tidak mempengaruhi perubahan diameter pembuluh darah dalam otak. Sebab bila proses pengeluaran $\mathrm{CO}_{2}$ kacau, maka $\mathrm{CO}_{2}$ yang ke luar juga kacau sehingga menyebabkan pembuluh darah di otak akan melebar berlebihan ketika kadar $\mathrm{CO}_{2}$ di dalam otak menurun. Sehingga, ditinjau dari ilmu saraf, terdapat hubungan yang erat antara pelafalan huruf (makharij al-huruf) pada bacaan dzikir dengan aliran darah pernapasan ke luar yang mengandung zat $\mathrm{CO}_{2}$ dan proses yang rumit di dalam otak pada kondisi fisik atau psikis seseorang.

Manfaat dzikir menurut Ahli Metafisik adalah untuk menarik energi positif ${ }^{33}$. Agar energi dzikir yang bertebaran di udara dapat masuk dan tersirkulasi ke seluruh bagian tubuh pelaku dzikir. Manfaat utama energi dzikir pada tubuh adalah sebagai pendingin guna menjaga keseimbangan suhu tubuh,

kuatnya tekanan terhadap makhraj huruf tersebut. Huruf jahr itu ada 18

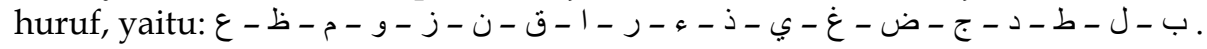
(Lihat di: Annisa Naiya Asyafa, Dampak Dzikir Terhadap Kesehatan, http://www.kesehatandanislam.blogspot.com)

${ }^{33}$ Energi positif adalah salah satu energi alam yang bersifat dingin karena dipengaruhi oleh suhu dingin atmosfir. Sedangkan energi alam (di bawah atmosfir) merupakan bagian dari udara. Energi alam berwujud butiranbutiran/partikel-partikel udara yang sangat halus dan tidak nampak oleh mata telanjang. Energi alam berasal dari hasil reaksi pembakaran sari makanan pada tumbuhan yaitu oksigen. Ada dua jenis energi alam, yaitu energi alam positif (energi positif), sebagaimana telah dijelaskan di atas, dan energi alam negatif (energi negatif), yaitu energi alam yang bersifat panas karena dipengaruhi oleh suhu panas uap bumi dan suhu panas dari sinar matahari. Satu energi positif sebanding dengan satu energi negatif. Keduanya saling tarik dan saling mengalahkan. 
agar tercipta "suasana kejiwaan yang tenang, damai dan terkendali, bermoral (berakhlakul karimah)". Kondisi kejiwaan yang demikian akan menentukan "kualitas ruh" makhluk, dimana ruh adalah penentu pertanggungjawaban makhluk di hadapan Allah swt.

Manfaat dzikir dalam tinjauan Ilmu Agama adalah untuk mendapatkan energi dzikir dari udara dengan tingkat kepadatan molekul energi yang terpadat dan terbesar. Salah satu manfaat beriman (yakin dan percaya) adalah untuk memadatkan energi dzikir ke dalam tubuh. Salah satu manfaat taqwa (bersedia menjalankan perintah Allah swt. dan menjauhi segala laranganNya) adalah untuk mengikat energi dzikir agar tidak mudah hilang atau menguap.

Bacaan dzikir merupakan kunci pintu masuknya energi dzikir ke dalam tubuh. Salah satu manfaat ikhlas adalah untuk memperlancar jalan masuknya energi dzikir ke dalam tubuh sebagai pelumas. Salah satu manfaat sabar adalah untuk memperbesar daya tampung tubuh pelaku dzikir terhadap energi dzikir yang masuk. Salah satu manfaat khusu' (konsentrasi) adalah untuk mempercepat proses masuknya energi dzikir ke dalam tubuh sebagai pemompa. Salah satu manfaat taubat adalah untuk mengeluarkan energi negatif dan energi kotor dari dalam tubuh pelaku dzikir, dan hal tersebut di atas terjadi dengan sendirinya (otomatis). Energi dzikir yang besar pada diri pelaku dzikir akan membentuk medan magnet positif atau daya tarik positif, yang bermanfaat untuk menarik makhluk Allah swt. yang lainnya untuk berpikiran positif dan berbuat positif terhadap si pelaku dzikir tersebut. Jadi, jika ibadah atau dzikir kita sudah benar menurut Allah swt. (alQur'an) dan Rasul-Nya (Sunnah) maka nasib hidup kita di dunia sekarang maupun di akhirat nanti akan selalu bahagia. ${ }^{34}$

34 Habib Huda, Wacana Waroeng Psikologi (Semarang: Candi Penataran Selatan 8B Kalipancur, 2004) http://www.makalah-ibnu.blogspot.com (Diakses tanggal 11 Mei 2011). 


\section{Penutup}

Hidup manusia di dunia ini ternyata bukanlah sekedar hidup, akan tetapi mempunyai makna hidup dalam menjalani hidupnya, yaitu untuk abdi/beribadah dan khalifah di dunia ini. Untuk mencapai makna hidup, maka manusia harus selalu menyucikan fitrahnya, agar naluri yang cenderung untuk mencari dan mengenal Allah swt. bisa selalu terjaga. Dengan fitrahnya itu mengarahkan manusia untuk cenderung mencari kebenaran dan keinginan akan makna hidupnya. Apabila hasrat untuk hidup bermakna ini terpenuhi maka kehidupan akan terasa berharga.

Manusia merupakan kesatuan utuh dimensi-dimensi ragawi, kejiwaan, dan spiritual. Dimensi-dimensi ini hanya dapat dibedakan, tetapi tidak dapat dipisahkan satu sama lain. Artinya, tanpa keterpaduan utuh semua dimensi tersebut, manusia tidak dapat disebut "manusia". Karena dimensi spiritual adalah hakikat kemanusiaanya.

Dimensi ini demikian penting, yang di dalamnya terdapat sumber potensi, akhlaq, ketauhidan, dan kualitas khas insani yang lainnya. Kuatnya spiritualitas dapat menjadikan manusia yang sehat dan paripurna. Sehingga tidak rentan terhadap problem-problem yang berawal dari spiritualitas, seperti kecemasan, kehampaan makna, frustasi eksistensial dan lain-lain. Sedangkan jalan dan metode untuk meningkatkan spiritualitas adalah dengan ilmu dan amal yang berlandaskan pada al -Qur`an.

Dzikir sebagai tradisi di pesantren dalam mengamalkan dengan kekhusu'an, niat yang baik, ikhlas dan yakin akan kebesaran Allah swt. niscaya akan menuntun hambaNya untuk selalu dekat kepada Allah swt. meningkatkan ketaqwaannya dan mendapatkan ridhaNya. KeridhaanNya akan terjelma dalam jiwa hamba berupa ketenangan pikiran maupun perasaan, serta keikhlasan dalam menjalankan kehidupan ini. Terciptanya ketenangan, kenetralisiran pikiran, dan perasaan 
hamba akan mampu membangun metabolisme fisik dan ketahanan mental hamba yang membiasakan diri memperbanyak dzikir kepada Allah swt.

Dengan demikian, dzikir memiliki daya terapeutik yang tinggi, baik bagi kualitas kesehatan fisik maupun psikologis manusia, yang akan ikut menjamin kualitas hidup di dunia dan akhirat. Itulah sebabnya amalan dzikir yang dahulu hanya sekadar dianggap tradisi ibadah semata, saat ini justru menjadi salah satu aspek kegiatan keagamaan yang menjadi acuan dalam unsur praktik terapikalistik di dunia kedokteran, terutama pada praktik terapi gangguan kejiwaan, dengan harapan hidup manusia menjadi bermakna bukan saja bagi dirinya tetapi juga orang lain baik itu di dunia maupun di akhirat sesuai kodrat manusia.

\section{Daftar Pustaka}

Abidin, Zaenal. Dzikir Suatu Tradisi Pesantren Menuju Terapeutik Depresif (Kajian Menuju Terapi Psikosomatik dan Neurosis). Jurnal Studi Islam \& Budaya P3M STAIN Purwokerto, Vol. 4, No. 1. (Januari-Juni 2006).

Amin, M. Aziz, Tirmidzi Abdul Majid. Analisa Dzikir dan Doa. Jakarta: Pinbuk Press, 2004.

Anshori, M. Afif. Dzikir Demi Kedamaian Jiwa Solusi Tasawuf atas Manusia Modern. Yogyakarta: Pustaka Pelajar, 2003.

Aziz al-, Moh. Saefullah. Risalah Memahami Ilmu Tasawwuf. Surabaya: Terbit Terang, 1978.

Bastaman, Hanna Jumhana. Integrasi Psikologi dengan Islam: Menuju Psikologi Islami. Yogyakarta: Pustaka Pelajar, 1995.

Behbehani, Soraya Susan, The Messenger Within, terj. Cecep Ramli, Ada Nabi dalam Diri. Jakarta: Serambi Ilmu Semesta, 2003.

Bruinessen, Martin Van. Kitab Kuning: Pesantren dan Tarekat. Bandung: Mizan, 1995. 
Dhofier, Zamakhsyari. Tradisi Pesantren: Studi Tentang Pandangan Hidup Kyai. Jakarta: LP3ES, 1982.

E, Koeswara. Teori-Teori Kepribadian. Bandung: Eresco, 1986.

Geertz, Clifford. Abangan, Santri, Priyayi dalam Masyarakat Jawa. Jakarta: Pustaka Jaya, 1983.

Jabbar, Syakir Abdul. Metode Ilmiah Bagi Suatu Akidah. Terj. Abd. Qadir Hamid. Jakarta: Duaputra Press, 2001.

K. Prenc.m, et al. Kamus Latin Indonesia. Yogyakarta: Kanisius, 1969.

Mahmud, Abdul Halim. Terapi dengan Dzikir Mengusir Kegelisahan \& Merengkuh Ketenangan Jiwa. Jakarta: PT. Mizan Publika, 2004.

Masyhudi, In'am Muzahiddin, Nurul Wahyu A. Berdzikir dan Sehat ala Ustadz Haryono. Semarang: Syifa Press, 2006.

Noer, Deliar. Pemikiran Politik Islam Santri. Jakarta: Panjimas, 1986.

Shiddieqy ash-, Hasbi. al-Islam. Jakarta: Bulan Bintang, 1977.

Tim Penyusun KBBI DEPDIKBUD, Kamus Besar Bahasa Indonesia. Jakarta: 1988.

Yasmadi. Modernisasi Pesantren: Kritik Nurcholish Madjid terhadap Pendidikan Tradisional. Jakarta: Ciputat Press, 2002.

http://www.detikislam.blogspot.com

http://www.id.wikipedia.org

http://www.ilmukesehatan.com

http://www.kesehatandanislam.blogspot.com.

http://www.makalah-ibnu.blogspot.com

http://www.psikologimania.com.

http://www.psychologymania.wordpress.com.

http://www.Sabdalangit.wordpress. com 